\title{
3 Abstract
}

4 The valuation of ecosystem services to inform natural resource management and development has 5 gained acceptance in many arenas. Yet, contemporary economic valuation is constrained to the 6 appraisal of simple goods that generate benefits that accrue to individuals, neglecting complex goods 7 that generate benefits that accrue to society more broadly. Methodological barriers to the valuation 8 of complex social goods have led to their frequent omission from natural resource management 9 deliberations. The prevailing valuation paradigm that focuses on simple individual goods may erode 10 conservation efforts by crowding out the institutions and behaviours that support socially constructed ecosystem service values. Erosion of these values ultimately harms the environment and society as a whole. The institutionalisation of appropriate methods for estimating the value of complex social goods alongside existing methods for valuing simple individual goods within international conservation, development and policy-making discourses, is therefore an important evolution for sustainable natural resource management.

\section{Keywords}


Natural resource management and development have long been informed by the economic valuation of various interrelated ecosystem services and over the past two centuries, these valuation methods have matured significantly. Putting a 'price' on nature allows decision makers to quantify and elucidate the myriad impacts of development. Efforts to "mainstream the values of biodiversity and ecosystem services into decision-making at all levels" are broadly recognized; non-market valuation is now firmly established in international policy discourses concerning natural resource use and conservation and is actively encouraged by state agencies through the publication of guidelines and handbooks (for example, Commonwealth of Australia, 2006; H.M. Treasury, 2003). There is, however, growing recognition that dominant valuation approaches make only a subset of benefits visible (Kenter et al., 2015) and that by focusing entirely on 'the market' and on market incentives, we may undermine the motivations and thus behaviors we seek to promote (Gneezy et al., 2011).

An emerging body of literature now recognizes a spectrum of value typologies (Vatn, 2009; Schwartz, 2015; Kenter et al., 2015). These typologies vary in complexity, but highlight that (at the simplest level), goods may be thought of as having (at least) two distinct dimensions-depicted as axes in Figure 1. Along the horizontal axis, goods range from simple, with separable benefits (e.g., food), to complex, with multiple, inter-related and inseparable benefits (e.g., wedding banquet). Along the vertical axis, benefits derived from goods range from individually constructed, reflecting individual motivations and 'utility' (e.g., ambition and success, respectively), to socially constructed, representing communal norms, relations, and expectations (e.g., social cohesion).

The various possible combinations of goods and benefits may be illustrated by different types of fisheries (Panel A, Figure 1), described in Table 1. As discussed in section 2 economists' ability to estimate values along these axes is variable. Hence, a limited range of goods has been assessed, with significant policy implications (discussed in section 3).

45

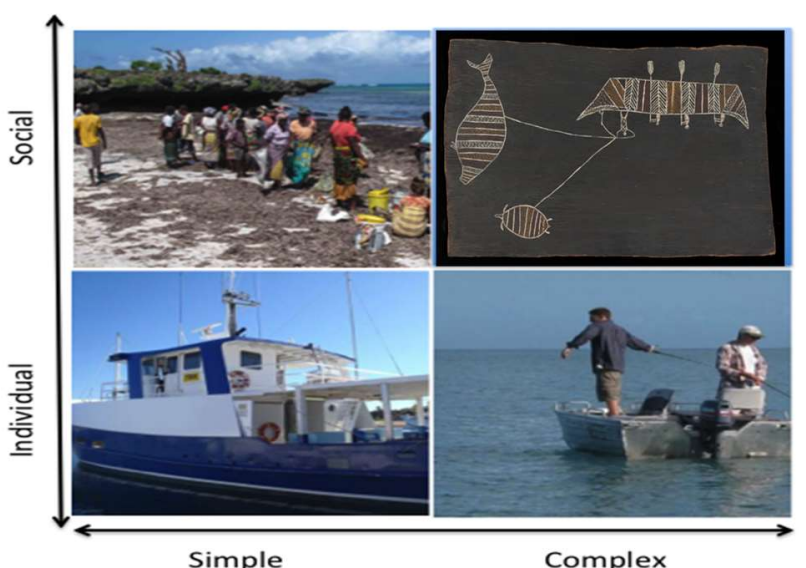

Panel A

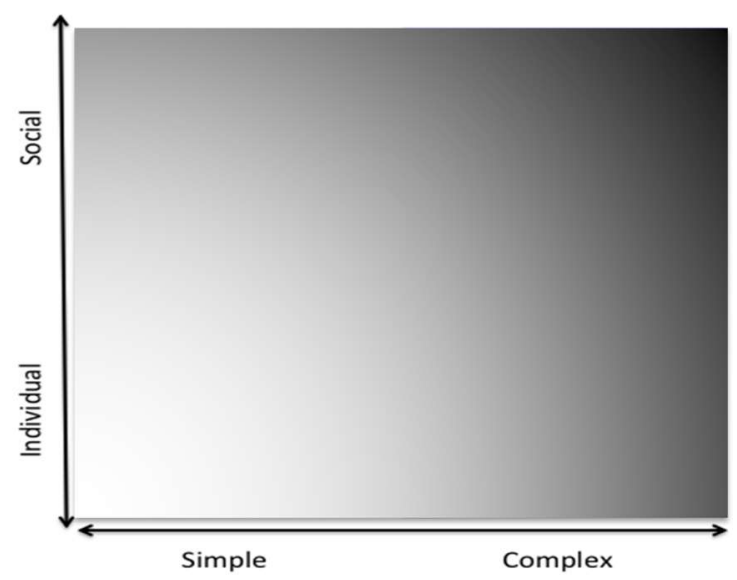

Panel B

Figure 1: Panel A: Various ecosystem services and their associated benefits may be visualised in two dimensions. Along one axis, goods range from simple to complex, illustrated here using different types of fisheries. Along the other, benefits range from individual to social constructs. Individually constructed benefits reflect individual 'utility.' Socially constructed benefits relate to social norms, relations, and expectations. Panel B: Established methodology sheds light on values relating to simple-individual goods (such as commercial fisheries) with other 
Table 1: Simplified typology of goods and benefits (derived from insights provided by Vatn 2009; Schwartz, 2015; Kenter et al. 2015)

\begin{tabular}{|c|c|c|c|}
\hline & & \multicolumn{2}{|c|}{ Type of good } \\
\hline & & Simple & Complex \\
\hline \multirow[t]{2}{*}{$\begin{array}{l}\text { Type of } \\
\text { Benefit }\end{array}$} & Individual & $\begin{array}{l}\text { Commercial fisheries are an example of a simple } \\
\text { good bearing individually constructed benefits. } \\
\text { Although the identify of commercial fishers is often } \\
\text { tied to their occupation (highlighting the } \\
\text { importance of cultural values to these fishers), the } \\
\text { primary motivation for commercial fishing } \\
\text { (particularly incorporated companies) tends to be } \\
\text { economic. The benefits associated with this industry } \\
\text { (e.g., contribution to GDP) are the sum outcome of } \\
\text { individual motivations and incentives to procure } \\
\text { income. }\end{array}$ & $\begin{array}{l}\text { Recreational fishing is an example of a } \\
\text { complex good that bears individually } \\
\text { constructed benefits. Recreational fishing } \\
\text { makes a contribution to individual utility - } \\
\text { although the contribution comprises } \\
\text { complex and antertwined } \\
\text { cultural/recreational and economic benefits. }\end{array}$ \\
\hline & Social & $\begin{array}{l}\text { Small-scale fisheries exemplify simple goods bearing } \\
\text { socially constructed benefits. They often provide an } \\
\text { economic safety net for vulnerable members of a } \\
\text { community. Such fisheries tend to feature strong } \\
\text { norms of fair access (Hicks et al., 2014), reciprocity } \\
\text { and taboos concerning trade-offs that promote the } \\
\text { fair distribution of benefits (Daw et al., 2015). In } \\
\text { many fisheries along the coast of the western Indian } \\
\text { Ocean, catch is distributed amongst a range of } \\
\text { stakeholders, including fishers, traders and small- } \\
\text { scale processors. When the take is plentiful, this } \\
\text { arrangement is predominantly financial. However, } \\
\text { when catches are low, the most vulnerable in } \\
\text { society (often widowed women) are assured } \\
\text { subsistence without financial exchange (Hicks et al., } \\
2014 ; \text { Daw et al., 2015). }\end{array}$ & $\begin{array}{l}\text { Traditional Indigenous fisheries are complex } \\
\text { goods bearing socially constructed benefits. } \\
\text { While the basic acts of hunting and fishing } \\
\text { may generate simple, individual benefits like } \\
\text { nutrition and income, the relations and } \\
\text { meanings formed through these practices' } \\
\text { associated norms, traditions, stories, and } \\
\text { ceremonies bear socio-cultural benefits } \\
\text { which are often more significant than the } \\
\text { individual benefits ( Delisle, 2013; Watkin Lui } \\
\text { et al., 2016). }\end{array}$ \\
\hline
\end{tabular}

\section{A very brief history of non-market valuation}

Although contemporary discourse about the 'value' of environmental goods and services is dominated by the concept of price (exchange value), this does not mean that economists believe price reflects value; rather, non-market valuation methods are firmly grounded in the broader idea of utilitarianism-i.e., value is a matter of usefulness (ideas largely attributable to Mill and Marshall). For most economists, the term utility represents the satisfaction that people gain from the use (or non-use) of a good or service; economists are thus concerned about people's satisfaction. For economists, maximizing someone's utility thus implies making that person as satisfied as possible. Many welfare and environmental economists have generalized this notion of utility to the level of society, whereby 'social utility' may be thought of as a measure of social welfare.

Environmental economists often seek to highlight the contribution that environmental goods and services make to individual or social welfare (utility/wellbeing) and have developed numerous methods of doing so. Below, we provide a brief (and non-definitive) summary of key events relevant to the development of these methods and of Cost-Benefit Analysis (CBA), an institutionalised framework for weighing up a variety of market and non-market costs and benefits (see Hanley and Spash, 1993, for a more comprehensive overview). We use Figure 2 to depict key contributing 
economists, concepts and policies chronologically, providing a notional measure of the growth in our 'knowledge' of values and valuation methods with a yellow line (with undefined units of 'knowledge' measured on the vertical axis).

- Late 1800s/early 1900s. Mill and Marshall clarify the distinction between value and price, with the notion of utility-linked to the idea of individual, and potentially also social 'welfare' (or wellbeing)

- Early 1900s. Economists and social scientists collaborate frequently on research into individual and collective wellbeing (utility/welfare).

- 1930's. Influential economists-namely, Irving Fisher and Vilfredo Pareto-successfully argue that utility cannot be measured in a way that facilitates meaningful interpersonal comparisons (Kristoffersen, 2010). From this point, for almost a century, economists and social scientists largely pursue different research agendas relating to wellbeing/utility/welfare.

- $\quad$ The US Flood Control Act of 1936 (The Act). This act legislated construction of an unprecedented litany of civil infrastructure works and obligated the government to undertake flood control efforts in the interest of the "general welfare," so long as a development project's "benefits to whomever they may accrue are in excess of the estimated costs" (US Congress, 1936, p. 1570). The Act established a concrete policy imperative for research into the social costs and benefits of natural resource development. Critically, the Act established that the improvement of social welfare necessarily required one to account for a diverse range of potentially competing interests, but it did not specify how this was to be done.

- Late 1930s. Hicks (1939) demonstrated that the welfare gains or losses arising from the addition or removal of goods and services can be articulated in terms of 'income-equivalent' compensations. That is, the cost (or benefit) to an individual of the loss (or gain) in their access to a good can be calculated by determining how much remuneration would be required to compensate them for that loss (formally, to keep their utility constant).

- Late 1930s-early 2000s

- The Total Economic Value (TEV) framework slowly developed, helping to clarify ways in which people benefit from the environment. Simplistically, the contemporary version of the framework identifies three broad categories: 'direct use values', where people benefit from the direct use of environmental goods and services (e.g., agriculture); 'indirect use values', where people benefit indirectly from the environment (e.g., from soil substrate water filtration-see Ciriacy-Wantrup, 1955, for an early discussion of these benefits); and 'non-use values', where people benefit from the environment without using it-as for existence values (e.g., knowing the environment is there) and bequest values (e.g., leaving the environment intact for future generations) (Krutilla, 1967); and option values (e.g., maintaining the environment for potential future use) (Weisbrod, 1964).

- Numerous methods for estimating the 'income-equivalent' compensations (interpreted as 'value') of the different types of use and non-use values were developed (see Appendix A for an overview). Some methods are only capable of estimating some values (e.g., the travel cost method can estimate recreational use-values, but cannot estimate bequest values). Each method thus generates subtly distinct information (e.g., expenditure, consumer surplus, willingness to pay) about different types of values. All methods are conditioned on assumptions, but two key assumptions dominate: first, that the constituents of utility are distinct, separable and additive (across goods and across people); and second, that income-equivalent compensations are an appropriate framing of economic trade-offs. 
- Most research concerning decision-making for improved social welfare was based on two compelling and related principles, inextricably linked to CBA. First, was the idea of a Pareto Improvement. Pareto argued that one could unambiguously improve social welfare if the welfare of at least one person increased, without negatively impacting the welfare of another. Second, was the notion of a Potential Pareto Improvement (with the related Kaldor-Hicks test, developed by Hicks and Kaldor (Broadway, 1974). It was noted that if the benefits of a project outweighed its costs, then the project could potentially improve social welfare since those who benefited would have more than enough to compensate those who lost.

- Early 21 $21^{\text {st }}$ century. The 2005 Millennium Ecosystem Assessment ignited broad interest in the contribution that ecosystem services make to human wellbeing. This further highlighted the need for policy makers to consider the 'value' of the environment more broadly, and thus increased interest in non-market valuation methods. It also served to focus attention on wellbeing, rather than exclusively on income-compensations or 'price'. Arguably, this new focus helped highlight wellbeing research undertaken by social scientists (with entire journals, e.g., Social Indicators Research, Journal of Happiness Studies, devoted to the topic).

- Recent decades. An increasingly vocal group of behavioural economists have argued that individual welfare (i.e., utility) may in fact be cardinal (Barberis, 2013), leading to the emergence of a new approach to valuation: the life-satisfaction (LS) approach (see, for example, Frey et al., 2009). Simplistically, this approach uses self-reported measures of (individual) well-being as proxies for utility (Gowdy, 2005) and regresses these measures against factors known to influence it (including environmental goods and services). LS thus enabled researchers to assess these ecosystem services' marginal value (to utility) directly, without needing to assess values as income-equivalent compensations (though that can also be done).

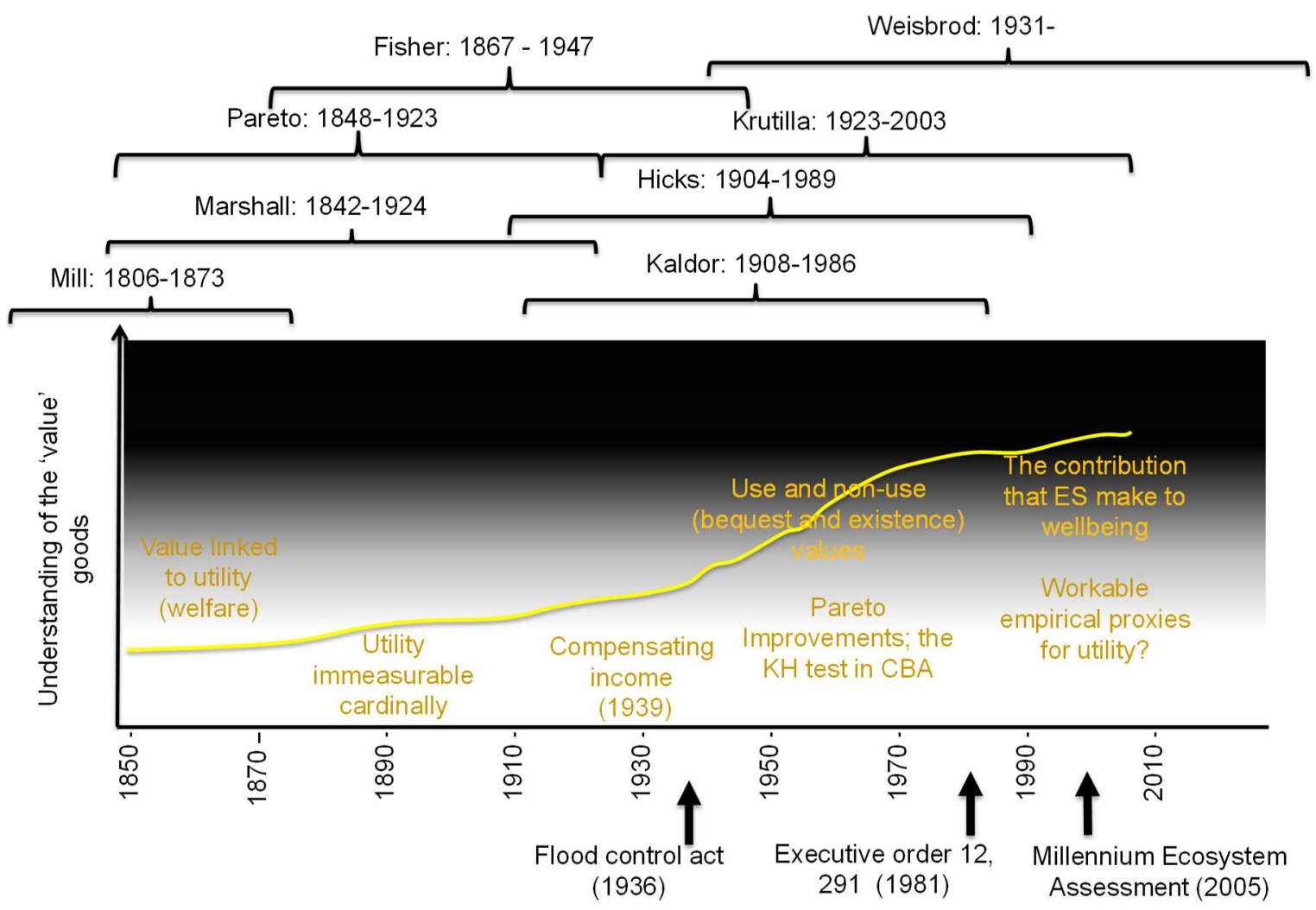


life-spans of (a subset of) key researchers (top), key concepts (middle - yellow font) and key policies/investigations (below axis) which contributed to the development of non-market valuation methods and methods for weighing up diverse market and non-market values (notably, CBA). Dark shades in upper diagram indicate values still poorly understood and thus 'in the dark'.

The US Flood Control Act of 1936 and subsequent institutionalisation of Cost Benefit Analysis (CBA) thus drove significant advancements in the sub-fields of welfare and environmental economics resulting in the identification of different types of goods and services, and the development of numerous related non-market valuation methods (Appendix A). The historical development of these methods means that most contemporary valuation exercises-and associated decision-making frameworks for aggregating the impacts of development, such as CBA-assume (even if only implicitly) that: (a) changes in social welfare may be assessed simply as the sum of each person's costs and benefits (conceptually, changes in their utility); (b) each person's utility depends on the utility they gain from each good and service they select; and (c) social welfare (utility) is the sum of individuals' utility.

The emphasis on ostensibly separable components of utility, measured at the individual level (individual good; individual person) and aggregated to the scale of society has narrowed the focus of (most) economic valuation exercises to a limited range of simple (separable) goods and services (Kenter et al., 2015). Techniques for estimating the value of simple individual goods (such as commercial fisheries, see Figure 1) are well established (assessing, for example, the value of output, of 'rent', see Appendix A). Though it can be difficult to estimate the value of complex individual goods (like recreational fishing, Figure 1) (Turner et al., 2003), methods and examples exist (see Appendix A for valuation techniques based on indirect market associations-e.g., travel cost method, hedonic pricing). Developments within the fields of behavioural and institutional economics have allowed promising innovations, particularly with regards to the conceptual inclusion of complex goods (Barberis, 2013), and the LS approach to valuation allows one to consider multiple values simultaneously. But the underpinning individualism of these approaches necessarily constrains common valuation exercises to the assessment of goods and services that generate 'utility' for individuals.

Thus, since the period immediately following the Act, when our knowledge about the value of nonmarket goods (and methods for assessing their value) grew rapidly, the rate of knowledge-growth has slowed (Figure 2). After passage of the Act, considerable research focused on developing neoclassical methods (which assumed utility to be measurable only in ordinal terms) to assess previously understood and newly identified use and non-use values. But since the late 1900s, attention has, arguably, been focused most ardently on the refinement of existing methods (e.g., on the development of more sophisticated econometric techniques for analysing data, on incorporation of insights from psychology into choice-modelling experiments). The development of LS comprises a notable exception. Although the difficulties of using existing methods to ascribe monetary value to complex social goods like Traditional Indigenous fishing and hunting (Figure 1) are widely acknowledged (Altman \& Whitehead, 2003; Vent and Quiggin, 2007), relatively little attention has been given to the development of new methods capable of doing so. Since the early 1900s, research has thus shed much light on the 'value' of individual goods (particularly simple ones) but, in comparison, we are still very much in the dark when it comes to understanding the 'value' of complex social goods (Panel B, Figure 1). 


\section{The crowding out of social values, institutions and norms}

192 "Motivational crowding" has already been shown to occur as a result of economic interventions 193 (Gneezy et al., 2011; Agrawal et al., 2015). Significantly, the prevailing valuation paradigm that 194 focuses on individual goods may also contribute to the erosion of conservation efforts and thus 195 degradation of the environment by crowding out the values, institutions and norms (akin to motivations) that support socially constructed ecosystem service values.

197 Every social context can be understood as an institution, in that there are rules and norms that signal appropriate behaviour (Vatn, 2009). Different social contexts support particular rationalities and emphasize distinct value types. We reason differently as economic actors in the market, for example, than we do amongst family and friends. Thus certain institutions support simple individual goods (e.g., food items) whereas others support complex social goods (e.g., a wedding feast), and each influences how people behave. An economic valuation exercise is no different in that it imposes a set of rules and norms concerning how decisions are to be made (Jacobs, 1997). These rules flow from the valuation method and dictate what is to be investigated and is thus of value, and characterize the goods and benefits (i.e., as simple, complex, individually or socially constructed) (Vatn, 2009). The valuation exercise engages these elements according to its self-delineated analytical framework, ascribing importance to various factors in accordance with prevailing assumptions, conventions and priorities. When conducting a valuation exercise, we are thus imposing an institution-with associated assumptions-that prioritises values at the individual level. Ostrom (1990) and Ostrom et al. (1999) clearly demonstrate that common pool resources are not necessarily doomed to the tragedy of the commons, and that alternative systems and institutionsespecially those that draw upon multiple forms of social capital-are adept to deal with complex natural resource management problems. Yet the institutionalisation of CBA and the valuation exercises that support it serves to inadvertently undermine these other frameworks, norms, behaviours and bodies of knowledge.

Figure 3 depicts the mechanism by which this happens and the impact it has on individual and social wellbeing. Discussed above, the prevailing paradigm (i.e., CBA) emphasises individual utility over broader notions of social value (Figure 3, a). Illustrated below, the institutionalisation of valuation methodologies that prioritise the individual serves to crowd-out social goods (Figure 3, b) and socially constructed corporate and political decision-making processes (Figure 3, c). This crowdingout undermines social norms and behaviours that impact the environment (Figure 3, d). Discussed in Section 4, the marginalisation of socially constructed institutions and subsequent degradation of the environment may have direct and indirect negative impacts on social welfare (community wellbeing). 
(a) Notions of human wellbeing and 'value'

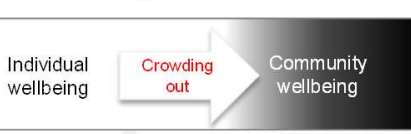

(b) Recognition of environmental values

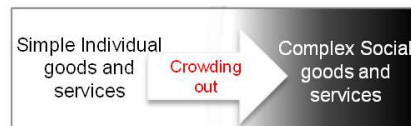

(c) Decision making processes/instituions

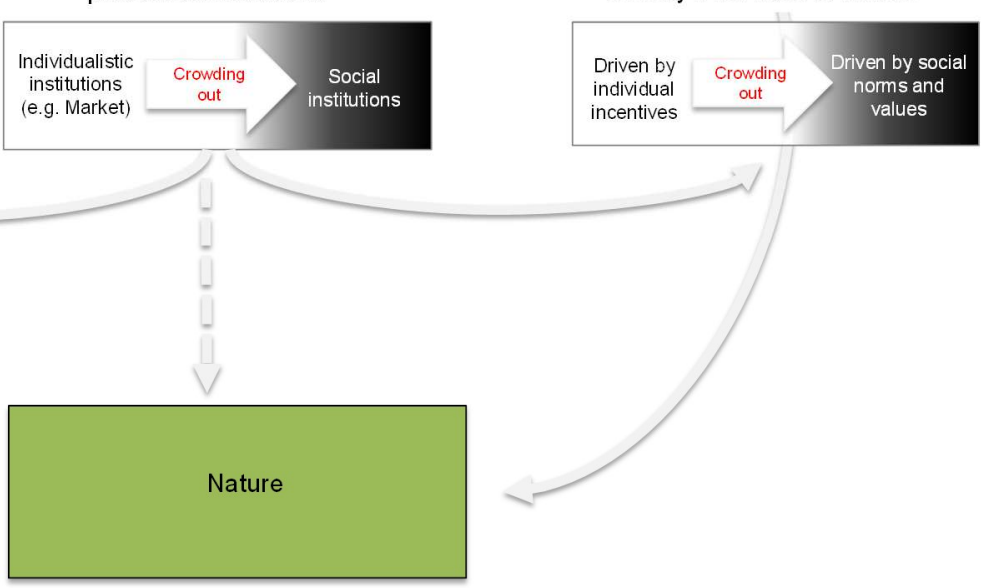

Figure 3: The crowding out of social goods, institutions and norms that support the environment and community wellbeing. CBA and associated non-market valuation techniques (a) prioritize individualistic notions of human wellbeing over other social constructs thus crowding out: (b) complex social goods and services; (c) socially constructed decision-making frameworks; and (c) social norms associated with stewardship behaviours. These socially constructed values, institutions and norms directly support community wellbeing; they also support the environment, so efforts to protect nature using methods that adopt exclusively individualistic perspectives which crowd-out social perspectives will not unambiguously improve social welfare (community wellbeing)

In contrast to simple individual goods, complex social goods (such as those associated with Indigenous Protected areas that generate multiple simultaneous cultural and provisioning benefits, amongst others) are typically only discussed in qualitative terms or obscured altogether (Figure 4, supported by supplementary e-materials). Economic logic suggests that, ceteris paribus, spending should be directed to programs with the greatest benefit per dollar spent. If, due to their complexity or because we lack methods for assessing them, entire classes of benefits are routinely omitted from deliberations, spending will invariably be directed towards interventions and projects that generate more easily monetized benefits (i.e., towards simple individual goods), rather than to projects that generate the greatest benefit, per se (at least some of which are likely to be associated with complex social goods). Our success in validating the value of simple individual goods may have unintentionally stifled our consideration of complex social goods and services that generate significant social and environmental benefits (Figure 1)-and may indeed crowd them out (Figure 3, b) by reducing investments in activities that support them, relative to activities that support simple individual goods. 

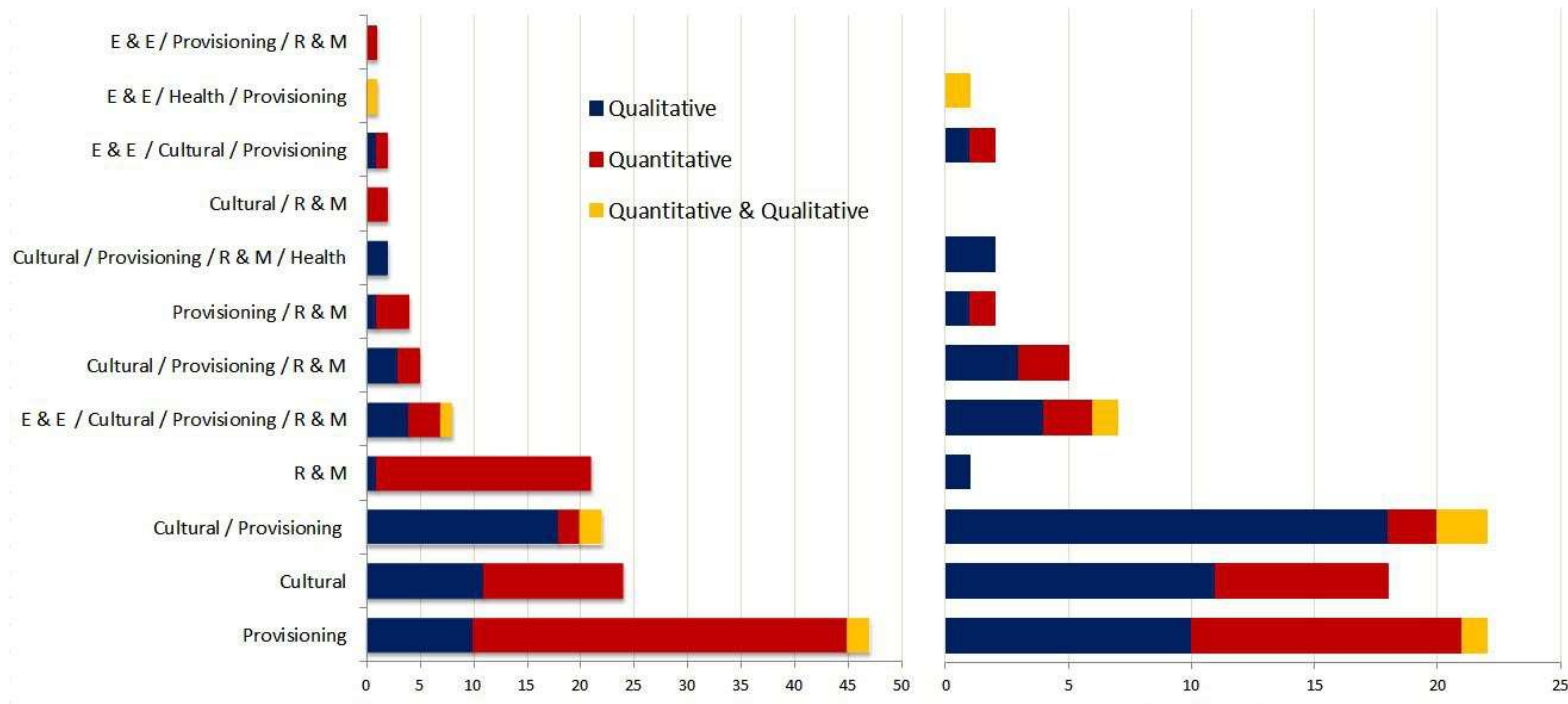

Figure 4: Studies referring to the 'value' of various benefits associated with protected areas in (a) general ( $\mathrm{N}=139)$ and (b) specifically Indigenous contexts $(\mathrm{N}=82)$, by general methodological approach. We undertook a nonexhaustive search of studies of protected areas (see supplementary e-materials for list of publications included) classifying them by type of ecosystem service considered (provisioning, regulation and maintenance (R\&M), and cultural). The categories of Health and Employment \& Enabling (E\&E) were added to capture other benefits associated with protected areas that are not always mediated through the environment. If studies considered more than one type of benefit (frequently complex social goods), all are listed.

Society accepts-explicitly and implicitly-that there are different classes of values and that certain trade-offs should be avoided (Vatn, 2009). Even if not explicitly asking about 'willingness to pay', most contemporary valuation methods assume that an ecosystem service may be ascribed a marginal value according to a beneficiaries' willingness to forgo its benefit in exchange for monetary recompense (Hick's compensating income). This framing contrives the price at which an otherwise socially unacceptable trade-off may be sanctioned. By assuming the additively separable nature of the benefit itself, the exercise also implies that an individual may forgo receipt of a benefit without reducing the value of the ecosystem service that underlies it. Yet a socially constructed benefit-the cultural significance of the undeveloped natural environment to its Indigenous traditional owners, for example-cannot, by definition, be divided into constituent partial values. The socially constructed value of an ecosystem service is inextricably linked to the communal experience of its benefit; to erode one's personal benefit is to erode the benefits of all. The neo-classical estimation of hypothetically disaggregated values posits trade-offs predicated on individualized incentives. This belies the true nature of the social good and trivializes difficult decisions regarding the best course of action for society as a whole. At what price should an individual forgo one's culture, religion or social identity? By attempting to commodify complex social goods, the valuation exercise compromises their values (Adamowicz et al., 1998) (Figure 3. b).

Moreover, most valuation methods generate estimates by assuming that social welfare (or the total value of a good, or the net social benefit of a project) is the sum of individual welfares (or values, or net benefits). The simple aggregation of individual estimates of 'value' may be inappropriate in some contexts, particularly when values are held at the community-level (Adamowicz et al., 1998). There is widespread agreement that benefits associated with the environment are frequently interdependent (i.e., 'complex'); researchers who aggregate partial estimates purportedly risk doublecounting 'overlapping values' (Hein et al., 2006). Yet this framing implicitly precludes the possibility that inter-dependent values may be synergistic-that the whole may comprise more than the sum of its parts. As the value of a shoe is critically diminished in the absence of its partner, so too may 
shared social values be fundamentally complementary. Indigenous peoples, for example, often accumulate knowledge and wealth at the community-level-particularly values associated with cultural integrity and continuity (Chan et al., 2012). This is another way by which the use of individualistic valuation approaches for social goods (complex or otherwise) may serve to undermine social values (Figure 3. b).

Critically, the omission of complex social goods in valuation exercises may also have unintended implications on existing values and behaviours. The institutionalisation of CBA has crowded out alternative systems and institutions capable of dealing with complex natural resource management (Ostrom, 1999, 2010) (Figure 3, c) and the framing of environmental issues in monetary terms may weaken intrinsic values and social norms crucial to the promotion of the public good (Gneezy et al. 2011). The financial incentivisation of environmental stewardship, for example, has been shown to undermine supporting motivations and behaviours (Agrawal et al., 2015), and to increase the costs of natural resource management and community change processes (Larson and Brake, 2011). This may marginalise social norms and behaviours imperative to environmental protection (Figure 3, d).

\section{Potential impacts on wellbeing}

CBA and the individualistic valuation methods that support it contribute to the crowding out of social goods, institutions and norms that support the environment. They may thus have the unintended consequence of indirectly contributing to environmental degradation. Whether or not that degradation associated with the loss of social goods, institutions and norms outweighs the (individualistic) positive impacts that $\mathrm{CBA}$ and valuation may have upon the environment remains an empirical question.

But there are other ways in which individual and social wellbeing may be affected. First, the crowding out of social decision making frameworks has been shown to erode social capital, and this has a direct negative impact on individual welfare (Achor, 2011), and may also bear environmental consequences, known to be related to wellbeing. Second, the non-market valuation techniques that support CBA (and other less structured decision making processes) are essentially voting systems weighted by personal wealth (Loomis, 2011). This is because willingness to pay (or amount actually paid) is, amongst other things, a function of ability to pay. Decision processes that use estimates generated from these methods may thus inadvertently privilege the (net) benefits of the wealthy above those of the poor. While weights which correct for income differences are sometimes used within CBA-particularly in developing economies where income inequality is often extreme (Hanley and Barbier, 2009)-such practices are rare. Such practices are also rare in less structured decision making environments. The TEEB initiative (van der Ploeg and de Groot, 2010), for example, reports only the nominal value of various ecosystem services throughout the world, irrespective of sample income distributions (though TEEB does group countries by relative overall income for comparison). There is substantial empirical evidence linking individuals' environmental preferences with their income (Jacobsen and Hanley, 2009; Hicks et al., 2014) and evidence to suggest that in some contexts, the wealthy have more to gain from developments that erode the environment than the poor (Stoeckl et al., 2013). Natural resource management decisions informed by the naïve application of unweighted 'values' may thus be more inclined to approve projects that degrade the environment than other decision making processes while simultaneously exacerbating the growing global inequality of the past several decades (Jaumotte et al., 2013).

Third, inequality has been shown to impact individual and community wellbeing (Wilkinson, 1996, Wilkinson and Picket, 2010; Guy and McCandless, 2012). There are established methods for 
incorporating variables that account for equity (e.g., the distribution of income) within social welfare functions (SEN - REFS), but by design and intent, most valuation methods ignore distributional issues. In CBA, it is generally assumed that a net social benefit represents a potential Pareto improvement-with net social benefit represented as the sum of individually constructed benefits. It has been shown that raising the income (rewards) of one individual without lowering the income (rewards) of another can generate significant discord of individuals who do not receive the higher income (reward) (Brosnan and De Waal, 2003). Unless monetary estimates of the 'costs' of social discord and 'benefits' related to equality are included in CBAs, one cannot assume that the measured net benefits represent a genuine Pareto improvement (since certain costs and benefits have been omitted from the assessment).

\section{Conclusion}

The social estimation of value has been long unbound from the concept of 'price' that characterised economics until the mid- $19^{\text {th }}$ century. A dawning recognition of the non-market value of ecosystem services, bolstered by Hick's notion of compensating income, has inspired the burgeoning field of environmental economics and critically enhanced sustainable management of natural resources. Passage of the Flood Control Act further rooted the assessment of environmental values within mainstream natural resource management policy. Subsequent development of the TEV helped to elucidate many of the natural environment's non-use values, including recreational, cultural, nonuse, bequest and existence values. In turn, society's expanding comprehension of our innate interconnectedness with the environment has been complemented and further strengthened by the development of novel economic tools for assessing different types of use and non-use values, including, among others, travel cost (for recreational use-values), contingent valuation and contingent behaviour methods (arguably developed to assess non-use values, but also capable of assessing use-values).

As a conservation initiative, estimating the value of ecosystem services has done much to illuminate the benefits individuals derive from nature. But the emphasis on goods that generate individual benefits may serve to erode the values, institutions and norms that enhance and protect the environment, individual and community wellbeing. Whilst valuation practitioners have within their 'tool kit' a diverse array of models for estimating nature's contribution to individual utility, methods for highlighting the socially defined values of complex goods are relatively less well developed, and less politically accepted. So too are socially constructed methods for making decisions related to the environment. To continue to obscure these values within the public discourse, and (in the US) to rely upon CBA as the 'preferred' mechanism for assessing change, risks further erosion of the norms and behaviours upon which effective natural resource management depends. Additional research is therefore needed to improve our methods of enumerating the value of complex goods and for assessing the desirability of changes that may impact them.

Ostrom (1990) highlights the numerous examples of situations where non-individualistic approaches (such as those requiring private property) have successfully managed natural resources; evidently communal approaches can be successful. In Indigenous communities, some people retain dynamic traditional knowledge, practices and beliefs, evolved over thousands of years, transmitted from one generation to the next (Berkes, 2008). The authority to speak about (or to 'value') particular goods or services is often vested solely in community Elders (Venn and Quiggin, 2007). In these communities, it may thus be more appropriate to assess complex social values through community- 
371 driven group and deliberative approaches (Wilson and Howarth, 2002), than using the non-market 372 valuation approaches so commonly applied in other settings. As is true for neo-classical non-market 373 valuation approaches, no single approach is problem free, but we must give them more attention, 374 identifying, for example, the contexts in which these other approaches are most/least appropriate.

375 To conclude, we note that CBA does not ask, "What is right for society as a whole?" but rather, 376 "What would generate the greatest (net) benefit for individuals within society?" To focus exclusively 377 on what generates the greatest net benefit for individuals risks a crowding-out of social goods, 378 institutions and norms that support the environment and individual and community wellbeing. The 379 importance of these social constructs calls upon us to consider principles of public interest, not just 380 principals of private/individual gain or loss. The challenge, of course, is to work out what those 381 principles are (or once were). 


\section{Acknowledgements}

384 We would like to acknowledge the financial support provided to us by the Australian

385 Government's National Environmental Science Program (Northern Australia Environmental

386 Resources Hub), by James Cook University and by the University of Lancaster. 


\section{References}

1. Achor S. 2011. The happiness advantage: The seven principles of positive psychology that fuel success and performance at work. New York, NY: Virgin Books.

2. Adamowicz W, Boxall P, Williams M, and Louviere J. 1998. Stated preference approaches for measuring passive use values: choice experiments and contingent valuation. Am J Agr Econ 80: 64-75.

3. Agrawal, A., A. Chhatre, and E.R. Gerber. 2015. Motivational Crowding in Sustainable Development Interventions. American Political Science Review 109 (3):470-487.

4. Altman, J., \& Whitehead, P. 2003. Caring for country and sustainable Indigenous development: Opportunities, constraints and innovation. Working Paper No. 20/2003: CAEPR. Retrieved from http://www.anu.edu.au/caepr

5. Arrow, K.1950. A difficulty in the concept of social welfare. The Journal of Political Economy, 328-346.

6. Awatere, S.B. 2008. The Price of Mauri - Exploring the validity of Welfare Economics when seeking to measure Mātauranga Māori. A thesis submitted in partial fulfilment of the requirements for the degree of $\mathrm{PhD}$, The University of Waikato, NZ.

7. Baker, R., \& Ruting, B. 2014. Environmental Policy Analysis: A Guide to Non-Market Valuation, Canberra: Productivity Commission Staff Working Paper.

8. Barberis NC. 2013. Thirty years of prospect theory in economics: A review and assessment. J Econ Perspect 27: 173-195.

9. Barbier, E. B. 1994. Valuing environmental functions: tropical wetlands. Land Economics, 155-173.

10. Barbier, E. B. 2007. Valuing ecosystem services as productive inputs. Economic Policy, 22(49), 177-229.

11. Bateman, I. J., Carson, R. T., Day, B., Hanemann, M., Hanley, N., Hett, T., . . Özdemiroglu, E. 2002. Economic valuation with stated preference techniques: a manual. Economic valuation with stated preference techniques: a manual, Cheltenham: Edward Elgar.

12. Berkes F. 2008. Sacred Ecology. Second Edition, New York, NY: Routledge.

13. Boadway, R.W., 1974. The welfare foundations of cost-benefit analysis. The Economic Journal, 84(336): 926-939.

14. Brosnan S and de Waal F. 2003. Monkeys reject unequal pay. Nature 425: 297-299.

15. Burke L, Greenhalgh S, Prager D and Cooper E 2008 Coastal Capital - Economic Valuation of Coral Reefs in Tobago and St. Lucia, World Resources Institute

16. Chan K, Satterfield T, and Goldstein J. 2012. Rethinking ecosystem services to better address and navigate cultural values. Ecol Econ 74: 8-18. 
17. Ciriacy-Wantrup, S.V., 1955. Benefit-cost analysis and public resource development. Journal of Farm Economics, 37(4): 676-689.

18. Commonwealth of Australia, 2006. Handbook of Cost-benefit analysis. ISBN 1921182032.

19. Costa, M. 2013. Social Return on Investment. In Encyclopedia of Corporate Social Responsibility (pp. 2238-2244). Springer Berlin Heidelberg.

20. Czembrowski, Piotr, and Jakub Kronenberg. 2016. "Hedonic pricing and different urban green space types and sizes: Insights into the discussion on valuing ecosystem services." Landscape and Urban Planning 146: 11-19

21. Daw T, Coulthard S, Cheung W, et al. 2015. Evaluating taboo trade-offs in ecosystems services and human well-being. PNAS 112: 6949-6954.

22. Day, B., Bateman, I. J., Carson, R. T., Dupont, D., Louviere, J. J., Morimoto, S., ... Wang, P. 2012. Ordering effects and choice set awareness in repeat-response stated preference studies. Journal of Environmental Economics and Management, 63(1), 73-91.

23. Delisle, A. 2013. A socio-economic investigation of the Torres Strait Indigenous dugong and turtle fisheries. (PhD Thesis), James Cook University, Townsville.

24. Farr, M., Stoeckl, N. Esparon, M., Grainger, D., and Larson, S. 2016. Economic values and Indigenous protected areas across Northern Australia. Darwin: Charles Darwin University. 67 pages.

25. Flood Control Act of 1936, H.R. 8455 C.F.R. § 6881936.

26. Frey B, Luechinger S, and Stutzer A. 2009. The life satisfaction approach to valuing public goods: The case of terrorism. Public Choice 138: 317-345.

27. Gneezy U, Meier S, and Rey-Biel P. 2011. When and why incentives (don't) work to modify behavior. J Econ Perspect 25: 191-209.

28. Gowdy, J.M., 2005. Toward a new welfare economics for sustainability. Ecological Economics $53,211-222$

29. Guy, M.E., and S.A. McCandless. 2012. Social equity: Its legacy, its promise. Public Administration Review 72 (s1):S5-S13.

30. H.M. Treasury. 2003. The Green book: Appraisal and evaluation in central government. London: The stationery office.

31. Hanley $\mathrm{N}$ and Barbier E. 2009. Pricing nature: cost-benefit analysis and environmental policy. Cheltenham: Edward Elgar Publishing.

32. Hanley, N., and C.L. Spash. 1993. Cost-benefit analysis and the environment. Cheltenham, UK: Edward Elgar Aldershot.

33. Hein L, Van Koppen K, De Groot R, and Van lerland E. 2006. Spatial scales, stakeholders and the valuation of ecosystem services. Ecol Econ 57: 209-228. 
34. Hicks C, StoeckI N, Cinner J, and Robinson J. 2014. Fishery benefits and stakeholder priorities associated with a coral reef fishery and their implications for management. Environ Sci Policy 44: 258-270.

35. Hicks, J. R. 1939. Value and Capital. Oxford: The Clarendon Press.

36. Jacobs M. 1997. Environmental valuation, deliberative democracy and public decisionmaking institutions. In: Forester J (Ed). Valuing Nature: Economics, Ethics and Environment. London: Routledge.

37. Jacobsen J and Hanley N. 2009. Are there income effects on global willingness to pay for biodiversity conservation? Environ Resour Econ 43: 137-160.

38. Jaumotte F, Lall S, and Papageorgiou C. 2013. Rising income inequality: technology, or trade and financial globalization? IMF Econ Rev 61: 271-309.

39. Kallis, G., Gómez-Baggethun, E., and Zografos, C. 2013. "To value or not to value? That is not the question." Ecological Economics, 94: 97-105.

40. Kenter JO, O'Brien L, Hockley N, et al. 2015. What are shared and social values of ecosystems? Ecol Econ 111: 86-89.

41. Kerr, G. N., \& Swaffield, S. R. 2012. Identifying cultural service values of a small river in the agricultural landscape of Canterbury, New Zealand, using combined methods. Society \& Natural Resources, 25(12), 1330-1339.

42. Kragt, M., Bennett, J., Lloyd, C., \& Dumsday, R. 2007. Comparing choice models of river health improvement for the Goulburn River. Paper presented at the 51st AARES Conference. Australia Queenstown.

43. Kristoffersen, I. 2010. The metrics of subjective wellbeing: Cardinality, neutrality and additivity. Economic Record, 86(272): 98-123.

44. Krutilla, J. 1967. Conservation reconsidered. The American Economic Review, 57(4): 777-786.

45. Larson S and Brake L. 2011. Natural resources management arrangements in the Lake Eyre Basin: An enabling environment for community engagement? Rural Society 21: 32-43.

46. Livermore, M., \& Revesz, R. 2013. The globalization of cost-benefit analysis in environmental policy (M. Livermore \& R. Revesz Eds.). New York: Oxford University Press.

47. Loomis J. 2011. Incorporating distributional issues into benefit cost analysis: why, how, and two empirical examples using non-market valuation. J BCA 2: 1-24.

48. Ostrom, E., Burger, J., Field, C.B., Norgaard, R.B. and Policansky, D., 1999. Revisiting the commons: local lessons, global challenges. science, 284(5412), pp.278-282.

49. Ostrom, E., 2015.Governing the commons. Cambridge university press.

50. Pascual, Unai, Mette Termansen, Katarina Hedlund, Lijbert Brussaard, Jack H. Faber, Sébastien Foudi, Philippe Lemanceau, and Sisse Liv Jørgensen. 2015. "On the value of soil biodiversity and ecosystem services." Ecosystem Services 15: 11-18. 
51. Prayaga, P., Rolfe, J., and Stoeckl, N. 2010, "The value of recreational fishing in the Great Barrier Reef, Australia: A pooled revealed preference and contingent behaviour model". Marine Policy 34(2): $244-251$

52. Rolfe, J., \& Windle, J. 2003. Valuing the protection of Aboriginal cultural heritage sites. Economic Record, 79 (Special issues), S85-S95.

53. Schwartz, S.H., 2015. Basic individual values: Sources and consequences. Handbook of value: Perspectives from economics, neuroscience, philosophy, psychology and sociology, pp.6384.

54. Spash C. 2008. Deliberative Monetary Valuation and the Evidence for a New Value Theory, Land Econ 84: 469-448.

55. Spash C. 2009. The new environmental pragmatists, pluralism and sustainability. Environ Value 18: 253-256.

56. Turner, R. K., Paavola, J., Cooper, P., Farber, S., Jessamy, V., \& Georgiou, S. 2003. Valuing nature: lessons learned and future research directions. Ecological economics, 46(3): 493510. doi:http://dx.doi.org/10.1016/S0921-8009(03)00189-7

57. Van der Ploeg S and de Groot R. 2010. The TEEB Valuation Database-a searchable database of 1310 estimates of monetary values of ecosystem services. Wageningen, The Netherlands: Foundation for Sustainable Development.

58. Vatn A. 2009. An institutional analysis of methods for environmental appraisal. Ecol Econ 68: 2207-2215.

59. Venn T and Quiggin J. 2007. Accommodating indigenous cultural heritage values in resource assessment: Cape York Peninsula and the Murray-Darling Basin, Australia. Ecol Econ 61: 334344.

60. Watkin Lui F, Stoeckl N, Delisle A, et al . 2016. Motivations for Sharing Bushmeat with an Urban Diaspora in Indigenous Australia. Hum Dimen Wildlife 21: 345-360.

61. Weisbrod, B. 1964. Collective-consumption services of individual-consumption goods. The Quarterly Journal of Economics, 78(3): 471-477.

62. Wilkinson R. 1996. Unhealthy societies - The afflictions of inequality. London: Routledge.

63. Wilkinson, R., \& Pickett, K. 2010. The spirit level - Why equality is better for everyone. London: Penguin Books Ltd.

64. Wilson M and Howarth R. 2002. Discourse-based valuation of ecosystem services: establishing fair outcomes through group deliberation. Ecol Econ 41: 431-443. 
APPENDIX A: Overview of traditional (neoclassical) non-market valuation techniques

\begin{tabular}{|c|c|c|}
\hline General approach & Specific examples & Comments \\
\hline \multirow{3}{*}{$\begin{array}{l}\text { Valuation techniques that use market prices: } \\
\text { Market prices exist only for goods which are bought and sold. So } \\
\text { these techniques are only able to provide information about } \\
\text { 'use-values' which are traded in the market and cannot quantify } \\
\text { many of the non-use values associated with the environment } \\
\text { such as cultural, existence and bequest values. }\end{array}$} & $\begin{array}{l}\text { Change in the value of } \\
\text { output (increase or } \\
\text { decreases in earning) }\end{array}$ & $\begin{array}{l}\text { This technique simply estimates the extra earnings (or losses) associated with } \\
\text { an environmental good or service (e.g., comparing farm production on soils } \\
\text { with varying biodiversity to draw inferences about the value of biodiverse soil } \\
\text { - Pascual et al., 2015). }\end{array}$ \\
\hline & $\begin{array}{l}\text { Preventative } \\
\text { expenditures } \\
\text { (damage avoided) }\end{array}$ & $\begin{array}{l}\text { This technique looks at how much people spend to prevent damages from } \\
\text { occurring to draw inferences about the 'value' of an ecosystem service that } \\
\text { does the same job (e.g., by estimating how much would be spent on } \\
\text { constructing sea walls to prevent beach erosion and storm damage, one can } \\
\text { estimate the 'value' of fringing coral reefs or mangroves which provide similar } \\
\text { protection (Burke et al, 2008)) }\end{array}$ \\
\hline & $\begin{array}{l}\text { Replacement cost or } \\
\text { Expected cost }\end{array}$ & $\begin{array}{l}\text { These approaches look at how much it does (or is expected to) cost to replace } \\
\text { damaged items (e.g., the cost of repairing buildings and businesses after } \\
\text { storm surge provides an estimate of the (regulating) value of wetlands which } \\
\text { reduce storm surge damage - Barbier, 1994, 2007). }\end{array}$ \\
\hline $\begin{array}{l}\text { Valuation techniques that use surrogate markets: } \\
\text { Revealed preference approaches do not require the goods that } \\
\text { one wishes to 'value' to be exchanged in the market, but they } \\
\text { require a strong connection between that good and the market } \\
\text { (e.g., house prices and 'views'; salaries/wages and workplace } \\
\text { safety). }\end{array}$ & $\begin{array}{l}\text { Hedonic pricing } \\
\text { (including wage } \\
\text { differential and } \\
\text { property or land value } \\
\text { approaches) }\end{array}$ & $\begin{array}{l}\text { This technique assumes that multiple things contribute to the 'value' of a } \\
\text { house (or car, or job) - some of which are associated with the environment. } \\
\text { Essentially, it is as if it compares the value of two houses which are identical in } \\
\text { all respects (e.g., number of bedrooms, bathrooms) except for one: proximity } \\
\text { to an urban park. The difference in house price between that which is near the } \\
\text { park and that which is not, gives an indication of the 'value' of the park } \\
\text { (Czembrowski and Kronenberg, 2016). }\end{array}$ \\
\hline $\begin{array}{l}\text { If one cannot establish a connection between the intangible } \\
\text { good to be valued and the market then one cannot use these } \\
\text { techniques. This is most likely to be the case for intangible } \\
\text { benefits associated with IPAs such as spiritual/cultural, bequest } \\
\text { and existence values, suggesting that these techniques cannot be }\end{array}$ & Travel cost & $\begin{array}{l}\text { This technique notes that even if entry to a park is 'free', people must spend } \\
\text { money travelling to and from it. The money spent travelling can be used to } \\
\text { draw inferences about the value of a park, an activity related to the park } \\
\text { (Prayaga et al., 2010), or the value of parks that are of different environmental } \\
\text { 'quality' (e.g., people will travel further and spend more to visit a well } \\
\text { maintained park than a degraded one). }\end{array}$ \\
\hline
\end{tabular}




General approach
used to monetise those benefits.

\section{Stated preference techniques:}

In principal, these techniques are capable of estimating the monetary 'value' of anything, including use and non-use values. People are asked how much they would be 'willing to pay' if a market did exist. The quality of the estimate is only as good as the quality of the experiment designed to elicit the 'value' - and there is a substantive body of literature that provides guidance on how best to describe the market and conduct the experiment. These techniques thus require the use of complex survey design, often draining to the respondents and requiring the use of sophisticated analytical procedures (Bateman et al., 2002; Day et al., 2012).

\section{Specific examples}

Acceptance of

compensation

Contingent valuation

Choice Modelling

\section{Comments}

This technique considers how much people have been awarded, in the courts, as 'compensation' for damages - using those estimates as a proxy for 'value' (Kallis et al., 2013).

Contingent Valuation (CV) involves the construction of 'hypothetical' markets. Individuals are asked to indicate their WTP to, for example, increase water quality/clarity to enjoy swimming, snorkelling or diving (Awatere, 2008).

Choice modelling (CM) differs from $\mathrm{CV}$, in that respondents are asked to choose between alternatives, rather than asked if they are willing to pay a price. CM involves the construction of numerous different 'choice-sets', each with different characteristics (e.g., differently levels of environmental amenity) and different prices. Individuals are asked to indicate which choiceset is preferred, and these preferences are used to draw inferences about the value of the different characteristics described in the choice-sets (Kerr and Swaffield, 2012; Kragt et al., 2007; Rolfe and Windle, 2003).

NB: Cost Benefit Analysis (CBA) and assessments of the Social Return on Investment (SROI) are occasionally referred to as non-market valuation methods. However, they are not, strictly speaking, non-market 'valuation' methods. Rather they are structured ways of aggregating monetised data about benefits and costs - weighting them against each other according to specific rules (e.g. including discount rates). In theory, a comprehensive CBA or SROI analysis includes monetised estimates of all benefits and all costs associated with the project/program being evaluated. Since many benefits and costs are not directly associated with the market, both CBA and SROI require researchers to undertake non-market valuation exercises (using techniques like those listed in the table above) to generate estimates of costs and benefits, for use in the wider analysis. See: Costa 2013 for further details on SROI. See Baker and Ruting 2014 for CBA. 